\title{
Waking, With Variations
}

\author{
Waking up drunk \\ Waking up hungry \\ Waking up pregnant \\ Waking up to a birthday \\ Waking up beside yourself \\ Waking up with no time to lose \\ Waking up like Sleeping Beauty \\ Waking up to the Doomsday Clock \\ Waking up in another language \\ Waking up with a lover \\ Waking up to the system \\ Waking up to yourself \\ Waking up as a human \\ Waking up angry \\ Waking up numb \\ Waking up \\ Waking
}

\section{Meeting Bessie Head in Adelaide, March 1984}

(i.m. 1937-86)

Cautiously, she gazed at us

through luminous-dark eyes -

the scrutiny of a writer.

The sky was pure cobalt

- an African sky, she laughed

standing there in bright florals

on an Adelaide street. Earlier

we'd heard her read to the Festival, bring a whole village to life.

- I hardly ever leave Botswana, my publishers arranged all this.

Then, like a postscript - I live in Botswana and don't trouble anyone. That way, I get on with my writing.

Get on with my writing - her words spun over our conversation, like reminders, warnings, juxtaposing her private and public face, the censorships she'd walked against carrying her testament - its knotted circle of words. 